УДК 792.82:39(=161.2)

DOI: $10.31866 / 2616-7646.2 .2 .2019 .188815$

\title{
УКРАЇНСЬКІ БАЛЕТИ ЯК ЕТНОМАРКЕРИ
}

\author{
Король Анастасія Миколаївна, \\ кандидат мистецтвознавства, \\ Київський національний університет культури і мистецтв, \\ Київ, Україна, \\ https://orcid.org/0000-0003-3498-432X, \\ korolnastya22aicloud.com
}

\begin{abstract}
Мета статті - виявити основні аспекти етномаркуючої ролі українських балетів. Методологія. У дослідженні використано аналіз наукової літератури, порівняння визначень поняття «українська національна балетна вистава», систематизація, мистецтвознавчий аналіз. Наукова новизна полягає в уточненні поняття «українська національна балетна вистава», виявленні етномаркерів в українських балетах. Висновки. Українські національні балетні вистави як елементи духовної культури виконують диференціюючу функцію, виступаючи своєрідними етномаркерами вітчизняного балету у світовій хореографічній палітрі. Попри функціональну непов’язаність балету із традиціями народного мистецтва, фольклор, синтезуючись із академічними хореографічними й музичними формами, призводить до виникнення своєрідного явища - української національної вистави. «Українська національна балетна вистава» - це балетна вистава, насичена елементами національної ідентифікації (світогляд, етичні, естетичні, психологічні особливості тощо); партитура з елементами народного мелосу; хореографія побудована на поєднанні/синтезі класичного танцю й українського танцювального фольклору. Зовнішні та внутрішні компоненти художнього образу в національних балетах етномарковані, вони втілюють суто хореографічні ознаки приналежності до українського етносу (лексика, малюнки тощо) та загальнонаціональні (менталітет, темперамент, моральні установки, поведінкові стереотипи тощо). Художній образ в цілому та його складники в національних балетних виставах набувають рис символу, що відіграє важливу роль в етномаркуванні на багатьох рівнях - образному, лексичному, просторово-композиційному, тематичному, атрибутивному й ін.
\end{abstract}

Ключові слова: українська національна балетна вистава, балет, етномаркер, хореографія, танець. 


\section{УКРАИНСКИЕ БАЛЕТЫ КАК ЭТНОМАРКЕРЫ}

\author{
Король Анастасия Николаевна, \\ кандидат искусствоведения, \\ Киевский национальный университет \\ культуры и искусств, \\ Киев, Украина, \\ https://orcid.org/0000-0003-3498-432X, \\ korolnastya22মicloud.com
}

Цель статьи - выявить основные аспекты этномаркирующей роли украинских балетов. Методология. В исследовании использованы анализ научной литературы, сравнение определений понятия «украинский национальный балетный спектакль», систематизация, искусствоведческий анализ. Научная новизна заключается в уточнении понятия «украинский национальный балетный спектакль», выявлении этномаркеров в украинских балетах. Выводы. Украинские национальные балетные спектакли как элементы духовной культуры выполняют дифференцирующую функцию, выступая своеобразными этномаркерами отечественного балета в мировой хореографической палитре. Несмотря на функциональную несвязанность балета с традициями народного искусства, фольклор, синтезируясь с академическими хореографическими и музыкальными формами, приводит к возникновению своеобразного явления - украинского национального спектакля. «Украинский национальный балетный спектакль» - это балетный спектакль, насыщенный элементами национальной идентификации (мировоззрение, нравственные, эстетические, психологические особенности и т. п.); партитура с элементы народного мелоса; хореография построена на сочетании/синтезе классического танца и украинского танцевального фольклора. Внешние и внутренние компоненты художественного образа в национальных балетах этномаркированы, они воплощают чисто хореографические признаки принадлежности к украинскому этносу (лексика, рисунки и т. п.) и общенациональные (менталитет, темперамент, нравственные установки, поведенческие стереотипы

\section{UKRAINIAN BALLETS AS ETHNOMARKERS}

\author{
Anastasiia Korol, \\ $\mathrm{PhD}$ in Arts, \\ Kiev National University \\ of Culture and Arts, \\ Kiev, Ukraine, \\ https://orcid.org/0000-0003-3498-432X, \\ korolnastya22aicloud.com
}

The purpose of the article is to identify the main aspects of the ethnomarking role of Ukrainian ballets. Methodology. The study used the analysis of scientific literature, a comparison of the "Ukrainian national ballet performance" concept's definitions, systematization, art history analysis. Scientific novelty lies in clarifying the concept of "Ukrainian national ballet performance", identifying ethnomarkers in Ukrainian ballets. Conclusions. Ukrainian national ballet performances as elements of spiritual culture play a differentiating function, acting as original ethnomarkers of domestic ballet in the world choreographic palette. Despite the functional incoherence of ballet with the traditions of folk art, folklore, synthesized with academic choreographic and musical forms, leads to the emergence of a peculiar phenomenon - the Ukrainian national ballet. «Ukrainian National Ballet Performance» is a ballet performance, saturated with elements of national identification, namely: worldview, moral, aesthetic, psychological characteristics and the like; score with elements of folk melos; choreography is based on a combination / synthesis of classical dance and Ukrainian dance folklore. The external and internal components of the artistic image in national ballets are ethnomarked - they are the embodiment of purely choreographic signs of belonging to the Ukrainian ethnic group (vocabulary, drawings, etc.) and national (mentality, temperament, moral attitudes, behavioral stereotypes, etc.). The artistic image as a whole and its components in national ballet performances acquire the features of a symbol, plays an important role in ethnomarking at many levels: figurative, lexical, spatial-compositional, thematic, attributive, and the like. 
и т. п.). Художественный образ в целом и его составляющие в национальных балетных спектаклях приобретают черты символа, что играет важную роль в этномаркировке на многих уровнях - образном, лексическом, пространственно-композиционном, тематическом, атрибутивном и др.

Ключевые слова: украинский национальный балетный спектакль, балет, этномаркер, хореография, танец.
Keywords: Ukrainian national ballet performance, ballet, ethnomarker, choreography, dance.

Актуальність теми дослідження. Глобалізаційні процеси сучасності викликають занепокоєння щодо збереження всієї множинності етносів, нівелювання національної ідентичності, одним із яскравих елементів якої є хореографічне мистецтво. Збереженню оригінального обличчя українського балетного театру впродовж багатьох років сприяють вистави національної тематики. Дослідження специфіки цього явища, а саме - етномаркуючої ролі, - актуальне завдання вітчизняної хореології.

Аналіз останніх досліджень і публікацій. Проблеми, пов'язані із проявами національного у вітчизняному балетному театрі, активно досліджуються науковцями в останні роки (Є. Ковалено (2013), Л. Козинко (2010), Л. Маркевич (2019), А. Підлипська (2017), Н. Семенова (2019), Т. Чурпіта (2018) та ін.). Однак досі немає праці, спеціально присвяченої з'ясуванню специфіки етномаркуючої функції української національної балетної вистави.

Мета дослідження - виявити основні аспекти етномаркуючої ролі українських балетів.

Виклад основного матеріалу. Українські національні балети стали своєрідним утіленням етнічної специфіки в балеті, деякі з них («Лілея», «Лісова пісня») піднялися до рівня символу вітчизняного театру. Ю. Бромлей (2008) стверджує, що в якості етнічних символів можуть виступати елементи духовної культури та виконувати етнодиференціюючу функцію й у такий спосіб відрізняти один народ від іншого (с. 127). Екстраполюючи це положення в площину балетного театру, можемо вести мову про маркуючу, диференціюючу роль українських національних балетів для вітчизняного театру у світовій хореографічній палітрі.

Одним із дискусійних питань у науковій літературі впродовж багатьох років залишається визначення поняття «національна балетна вистава», що підтверджують і найновіші дослідження. Л. Маркевич, аналізуючи поступ художньої мови української національної балетної вистави у 20-80-х рр. ХХ ст., звернулася для пояснення специфіки феномена до теорії знаків: «На знаковому рівні поєднання уніфікованих хореографічних та національних фольклорних мовних кодів починало свій розвиток від паралельного співіснування, формування фольклорносценічної знакової системи - до прояву знаків національної характерності на рівні образно-драматургічному, в цілому на рівні балетної форми, у вигляді ментальнопсихологічної знаковості» (Маркевич, 2019, с. 18-19). Вважаємо, що ці процеси не можна розглядати як еволюційні сходинки, паралельно відбувалося формування 
образної-драматургічної національно маркованої основи українських балетів, де проявлялися метально-психологічні особливості, проводились експерименти із синтезування лексики українського народного та класичного танцю, уведення до структури балетів композиційних форм, притаманних народному танцю.

Певну термінологічну невідповідність можна виявити у визначенні, поданому Н. Семеновою, котра під «українською національною балетною виставою» у вузькому розумінні пропонує «вважати балети, які створено на сюжети, запозичені з української усної народної творчості, літератури, та/або сюжети з минулого чи сучасного життя. В основі хореографічної драматургії - музичні партитури, створені українськими композиторами XX ст., які інтерпретують українські народні мелодії та/або створюють власні в найкращих національних традиціях. Пластичне вирішення таких вистав базується на синтезі досягнень класичної хореографії та виражальних засобів українського танцю». Недоречними сприймаються часові обмеження стосовно музики, мова йде лише про тематику та лексику таких вистав, що значно збіднює розуміння феномену української національної балетної вистави (Семенова, 2019, с. 10).

Ми дотримуємося підходів М. Ельяша (Эльяш, 1977), В. Уральської (Уральская, 1969), Е. Шумілової (Шумилова, 1976) та ін. до трактування поняття «національна балетна вистава», що вже, певною мірою, стали класичними в балетознавстві. Узагальнено визначення формулюємо таким чином: «українська національна балетна вистава» - це балетна вистава, насичена елементами національної ідентифікації (світогляд, етичні, естетичні, психологічні особливості тощо); партитура з елементи народного мелосу; хореографія побудована на поєднанні/синтезі класичного танцю й українського танцювального фольклору.

Феномен української балетної вистави можна розглядати крізь призму концепції фольклоризму, що дає змогу поглибити розуміння її природи. За В. Гусевим (1977), фольклоризм - це своєрідна форма захоплення фольклором та освоєння його в інших видах культури. Балетне мистецтво функціонально безпосередньо не пов'язане із традиціями народного мистецтва, тут діють інші механізми, ніж під час відтворення фольклору в сценічному просторі, припустимо, засобами народно-сценічного танцю. У балеті фольклор залучається до іншої системи виражальних засобів. Перетворення, трансформація фольклору задля органічного введення в контекст сценічного мистецтва - метод створення українських балетів. I не дивно, що першим українським балетом став балет «Пан Каньовський», основу якого визначила народна балада. Перші національні балети створювалися за сюжетами народних легенд, на темах героїчного епосу та образах пісенного фольклору.

В українських балетах відбувається часткове освоєння фольклорних форм танцю та лексичних елементів (рухів). Музичні партитури насичені мелодикою та модифікованими формами народних пісень, що передбачає хореографічне втілення в дотичних формах. Н. Шахназарова (1968) зазначає: «У професійній творчості досягається високий ступінь узагальнення характерних особливостей національної музичної мови» (с. 40). Відштовхуючись від музичних партитур, що були насичені народнопісенними та танцювальними мелодіями, формами, балетмейстери вдавалися до освоєння елементів фольклорного танцю (рухів) та архітектонічних побудов задля органічного втілення балетів національної тематики. 
Попри те, що звернення до фольклорних елементів не було детерміноване пробудженням національної самосвідомості, національної гідності, коли нація починає усвідомлювати, що вона покликана зіграти свою роль в історії цивілізації, а відбувалося в СРСР за чіткими ідеологічними настановами зі створення національних балетів в умовах багатонаціональної держави, такі вимоги до створення національного балету позитивно відбилися на усвідомленні своєрідності українського балетного театру. Справжнє ж зацікавлення фольклором, збирання зразків народної творчості ризикувало наштовхнутися на звинувачення в буржуазному націоналізмі. Виникав парадокс: з одного боку, за радянських часів стимулювалося прагнення до створення українського національного балетного театру, мови національної балетної вистави, а з іншого - знищувалися митці, які прагнули зберегти унікальні зразки українського фольклору, з мінімальними обробками вводили їх до репертуару аматорських та професійних колективів (розстріл В. Верховинця 1938 р. за звинуваченням у націоналізмі).

Хореографічний образ в українських балетних виставах є своєрідним виявом національного художнього мислення, тож природно, що він змінюється разом зі зміною цього мислення. «Модифікація художньо-образного мислення, - зазначає О. Бойко (2015), - детермінується... рядом факторів: зміною історичних, економічних, культурних умов життя і взаємозв'язків з іншими народами, трансформацією соціального змісту і національного характеру» (с. 54). Можна також вести мову про зовнішні та внутрішні компоненти хореографічного художнього образу. До зовнішніх відносимо рухи, положення тіла, міміку, жести, пози тощо, до внутрішніх - емоційність, чуттєвість сприйняття подій, думки, почуття. «Хореографічний образ - категорія естетична, під якою розуміємо конкретні чи узагальнені сцени життя, природи, створені балетмейстером за допомогою вигадки, асоціативного бачення і т. ін., які мають певну естетичну цінність. Це конгломерат типових рис, у яких найбільш точно і яскраво відображене певне життєве явище.... хореографічний образ з'явиться тільки тоді, як у танцюриста внутрішній монолог зіллється із зовнішнім його еквівалентом і буде вироблено своєрідну єдину кінетичну схему почуттів, і пластика стане не самоціллю, а засобом для створення хореографічного образу», - наполягає К. Василенко (1997, с. 131-132). I зовнішні, і внутрішні компоненти художнього образу в національних балетах етномарковані, вони втілюють суто хореографічні ознаки приналежності до українського етносу та загальнонаціональні (менталітет, темперамент, моральні установки, поведінкові стереотипи тощо).

Художній образ в цілому та його складники в національних балетних виставах набувають рис символу. У мистецтві й мистецтвознавстві цим терміном характеризується художній образ з погляду його значення (що він виражає, на що натякає). С. Безклубенко (2010) зазначає: «Цю особливість людської свідомості не лише помічати прямий і безпосередній зміст та смисл подій, фактів, дій, їх особливих характеристик та прикмет (зовнішнього вигляду, форми, світла, та тіні, кольору, звучання і т. д.), а й розкривати їх ніби приховане значення широко використовується у мистецтві для створення художнього образу й посилення його впливу. При цьому роль символу можуть виконувати і змістовні зображення, і засоби зображення, такі, зокрема, як світло, колір, звук тощо» (с. 140). 
В. Телеуця (2011) вважає символ в мистецтві універсальною естетичною категорією, «що розкривається через зіставлення із суміжними категоріями художнього образу, з одного боку, знаку, а з іншого - алегорії. Принципова відмінність символу в тому, що його не можна дешифрувати простим зусиллям розуму, він невіддільний від структури образу, не існує як певна раціональна формула, яку можна “вкласти” в образ, а потім - витягти із нього... Сама структура символу спрямована на те, щоб через кожне часткове явище дати цілісний образ світу» (с. 292). Наприклад, в українських балетах образ жінки часто піднімається до рівня символу, який залежно від контексту втілює молодість та красу, трагічну долю жіноцтва, жіночий початок української ментальності тощо.

Зважаючи на шлях синтезування лексики класичного та українського народного танцю, яким пішов український балет в реалізації національної теми, а також природну трансляцію елементів обрядово-побутової культури та глибинних світоглядних основ українців через образи національних балетів, правомірно вести мову про паралельність формування методики втілення образів народно-сценічної хореографії та балетів національної тематики. Особливо помітним для українських балетів став вплив балетмейстерської творчості П. Вірського в Державному ансамблі танцю УРСР, котрий створив унікальну мову академічного українського народно-сценічного танцю, зберігши глибинний зв'язок з розмаїтим комплексом фольклорно-танцювальної культури України. Розглянемо ці процеси на прикладі жіночих образів.

Насамперед варто зазначити, що жіночі образи в українській народносценічній хореографії тісно пов’язані з обрядово-побутовою культурою, якій притаманна складна система символів. Балетмейстери народно-сценічної хореографії, обробляючи фольклорні першоджерела, традиційно намагалися й намагаються зберегти глибинне символічне ядро твору. Найчисельніша група таких творів, що транслюють семантичну систему обрядових танців, - хороводи та хороводні танці. У більшості авторських творів, де за відсутності конкретних фольклорних танцювальних першоджерел хореографія гранично наближена за стилем до народної, опоетизований образ жінки сприймається як символ України. Яскравим прикладом такого твору є лірико-психологічна хореографічна поема «Про що верба плаче» в постановці П. Вірського. Балетмейстер у розгорнутих танцювальних монологах головної героїні майстерно передає душевні переживання й страждання, виражаючи ними глибинну сутність української дівчини: чистоту, сором'язливу ніжність, глибоку відданість коханому. У сцені проводів козака в далекий похід дівчина подає йому шапку та шаблю, що практично є відображенням традиції жіночого благословення перед військовим походом.

У хореографічній поемі «Подоляночка», створеній П. Вірським за мотивами подільського фольклору, жіночий образ уособлює типові риси української дівчини: цнотливість і пристрасність, гідність і самовідданість. У постановці «Рукодільниці» П. Вірський оспівує красу жіночої праці, опоетизовує традиційні для українок ремесла (килимарство) (Боримська, 1974, с. 80). Весняні образи природи втілено П. Вірським у мереживному танці дівчат-квіток у мініатюрі «Плескач».

Однією з вершин жіночого українського народно-сценічного танцю стала хореографічна картина «Вербиченька», поставлена О. Сегалем на музику М. Лисенка в аранжуванні А. Мухи, що зберігається в репертуарі ансамблю танцю ім. П. Вір- 
ського. Попри граничну простоту танцювальної лексики, у хореографічній картині втілено надзвичайно поетичний образ верби - символ весни, пробудження природи, адже верба з давніх-давен уособлює священне дерево. Номер пов’язаний зі всією системою народної культури українців, навіяний українськими традиціями та символікою: дівчата створюють вербу як уособлення України.

У хореографічній композиції «Веснянки», що входить до репертуару Українського академічного фольклорно-етнографічного ансамблю «Калина», балетмейстер В. Дебелий хореографічними засобами відтворив закликання весни, що у своїй прадавній основі є магічним обрядом. Хореограф уникає однотипної пластичної характеристики виконавиць, що сприяє різноманітнму тлумаченню дівочих образів: вони є й дівчатами у весняному танку, вони подібні й до перших птахів, які сповіщають про прихід весни, одночасно втілюють і різнокольорові весняні квіти як символ пробудження природи тощо.

До репертуару Ансамблю народного танцю «Київ» кафедри народної хореографії Київського національного університету культури і мистецтв входить хореографічна сюїта «Калинова Україна», де дівчата з калиновими гілками уособлюють красу, добробут, Україну. «Без верби й калини нема України» - одне з найвідоміших українських прислів'їв, що підтверджує символічність жіночих образів у танцях, пов'язаних 3 цими рослинами.

Отже, ряд жіночих образів українських народно-сценічних танців відображають глибинний смисл усієї міфологічно-обрядової системи українського народу, найчастіше символізують образ України - дівчини, неньки, охоронниці.

Своєю чергою, балетмейстери національних вистав («Пан Каньовський», «Лілея», «Лісова пісня», «Маруся Богуславка», «Відьма» й ін.) транслюють систему символів, що пов'язані з образом жінки у фольклорі. Балетмейстери в розгорнутих танцювальних варіаціях головних героїнь майстерно передають душевні переживання й страждання, виражають глибинну сутність української дівчини, жінки: чистоту, сором’язливу ніжність, глибоку відданість коханому, стійкість, духовну силу.

Наукова новизна полягає в уточненні поняття «українська національна балетна вистава» та у виявленні етномаркерів в українських балетах.

Висновки. Українські національні балетні вистави як елементи духовної культури виконують диференціюючу функцію, вони є своєрідними етномаркерами вітчизняного балету у світовій хореографічній палітрі. «Українська національна балетна вистава» - це балетна вистава, насичена елементами національної ідентифікації (світогляд, етичні, естетичні, психологічні особливості тощо); партитура з елементи народного мелосу; хореографія побудована на поєднанні/синтезі класичного танцю та українського танцювального фольклору.

I зовнішні, і внутрішні компоненти художнього образу в національних балетах етномарковані, вони є втіленням суто хореографічних ознак приналежності до українського етносу (лексика, малюнки й ін.) та загальнонаціональних (менталітет, темперамент, моральні установки, поведінкові стереотипи тощо). Художній образ в цілому та його складники в національних балетних виставах набувають рис символу, що відіграє важливу роль в етномаркуванні на багатьох рівнях образному, лексичному, просторово-композиційному, тематичному, атрибутивному й ін. 


\section{СПИСОК БІБЛОГРАФІЧНИХ ПОСИЛАНЬ}

Безклубенко, С. (2010). Мистецтво: терміни та поняття (Т. 2). Київ: Інститут культурології НАМ України.

Бойко, О. С. (2015). Художній образ в українському народно-сценічному танці [Монографія]. Київ: Видавництво Ліра-К.

Боримська, Г. (1974). Самоцвіти українського танцю. Київ: Мистецтво.

Бромлей, Ю. В.( 2008). Очерки теории этноса (2-е изд.). Москва: Издательство ЛКИ.

Василенко, К. (1997). Український танецьь. Київ: ІПК ПК.

Гусев, В. Е. (1977). Фольклор и социалистическая культура. В Современность и фольклор: Статьи и материалы (с. 7-27). Москва: Музыка.

Коваленко, Є. (2013). Хореографічна інтерпретація Шевченкової «Лілеї» в балеті Костянтина Данькевича (постановки В. Вронського, В. Ковтуна, В. Трощенка). Українське мистецтвознавство: матеріали, дослідження, рецензії, 13, 104-110.

Козинко, Л. (2010). Фольклорні елементи у балетмейстерській творчості Алли Рубіної. Сучасне мистецтво, 7, 297-308.

Луценко, О. (1997). Жіноче начало як культурологічний символ. (Автореферат дисертації кандидата філософських наук). Харківський державний університет, Харків.

Маркевич, Л. (2019). Трансформація системи художньої мови української національної балетної вистави в 20-80 роках XX ст. (Автореферат дисертації кандидата мистецтвознавства). Прикарпатський національний університет імені Василя Стефаника, Івано-Франківськ.

Підлипська, А. М. (2017). Репертуар балетного театру України кінця XX - початку XXI століття: типологія та проблеми. Вісник КНУКіМ. Серія: Мистецзтвознавство, 36, 86-93.

Семенова, Н. М. (2019). Національна балетна вистава в українській хореографічній культурі $X X$ - початку XXI століть. (Автореферат дисертації кандидата мистецтвознавства). Харківська державна академія культури, Харків.

Телеуця, В. (2011). Архетип як основа національного самоусвідомлення. Література. Фольклор. Проблеми поетики, 36, 291-300.

Уральская, В. (1969). Эстетические проблемы взаимовлияния народного и профессионального искусства (на материале хореографии). (Автореферат диссертации кандидата философских наук). Московский государственный институт культуры, Москва

Чурпіта, Т. (2018). Не народний, але заслужений: маловідомі сторінки творчої біографії Миколи Трегубова. Танцювальні студіï, 1, 6-16.

Шахназарова, Н. (1968). О национальном в музыке. Москва: Музыка.

Шумилова, Э. И. (1976). Национальное своеобразие балета. Москва: Знание.

Эльяш, Н. (1977). Балет народов СССР. Москва: Знание.

\section{REFERENCES}

Bezklubenko, S. (2010). Mystetstvo: terminy ta poniattia [Art: Terms and Concepts] (Vol. 2). Kyiv: Institute for Cultural Research of the National Academy of Arts of Ukraine [in Ukrainian].

Boiko, O.S. (2015). Khudozhnii obrazv ukrainskomu narodno-stsenichnomu tantsi [Artistic image in Ukrainian folk-dance] [Monograph]. Kyiv: Lira-K Publishing [in Ukrainian].

Borymska, H. (1974). Samotsvity ukrainskoho tantsiu [Gems of Ukrainian dance]. Kyiv: Mystetstvo [in Ukrainian].

Bromlei, Iu.V. (2008). Ocherki teorii etnosa [Essays on the theory of ethnos] (2 ${ }^{\text {nd }}$ ed.). Moscow: Izdatelstvo LKI [in Russian]. 
Churpita, T. (2018). Ne narodnyi, ale zasluzhenyi: malovidomi storinky tvorchoi biohrafii Mykoly Trehubova [Not people's, but honored: little-known pages of Mykola Tregubov's creative biography]. Dance studies, 1, 6-16 [in Ukrainian].

Eliash, N. (1977). Balet narodov SSSR [Ballet of the peoples of the USSR]. Moscow: Znanie [in Russian].

Gusev, V.E. (1977). Folklor i sotsialisticheskaya kultura [Folklore and socialist culture]. In Sovremennost i folklor: Stati i materialy [Modernity and Folklore: Articles and Materials] (pp. 7-27). Moscow: Muzyka [in Russian].

Kovalenko, Ye. (2013). Khoreohrafichna interpretatsiia Shevchenkovoi "Lilei" v baleti Kostiantyna Dankevycha (postanovky V. Vronskoho, V. Kovtuna, V. Troshchenka) [Choreographic interpretation of Shevchenko's "Lily" in the ballet of Konstantin Dankevich (productions by V. Vronsky, V. Kovtun, V. Troschenko)]. Ukrainske mystetstvoznavstvo: materialy, doslidzhennia, retsenzii, 13, 104-110 [in Ukrainian].

Kozynko, L. (2010). Folklorni elementy u baletmeisterskii tvorchosti Ally Rubinoi [Folklore elements in Alla Rubina's ballet master's work]. Suchasne mystetstvo, 7, 297-308 [in Ukrainian].

Lutsenko, O. (1997). Zhinoche nachalo yak kulturolohichnyi symvol [Feminine as a cultural symbol]. (Abstract of PhD Dissertation). Kharkiv State University, Kharkiv [in Ukrainian].

Markevych, L. (2019). Transformatsiia systemy khudozhnoi movy ukrainskoi natsionalnoi baletnoi vystavy $v$ 20-80 rokakh XX st. [Transformation of the system of artistic language of the Ukrainian national ballet performance in the 20-80s of the XX century]. (Abstract of PhD Dissertation). Vasyl Stefanyk Precarpathian National University, Ivano-Frankivsk [in Ukrainian].

Pidlypska, A.M. (2017). Repertuar baletnoho teatru Ukrainy kintsia XX - pochatku XXI stolittia: typolohiia ta problem [Repertoire of the Ballet Theater of Ukraine in the late XX - early XXI centuries: typology and problems]. Bulletin of KNUKiM. Series in Arts, 36, 86-93 [in Ukrainian].

Semenova, N.M. (2019). Natsionalna baletna vystava v ukrainskii khoreohrafichnii kulturi XX pochatku XXI stolit [National ballet performance in the Ukrainian choreographic culture of the $X X$ - the beginning of the XXI centuries]. (Abstract of PhD Dissertation). Kharkiv State Academy of Culture, Kharkiv [in Ukrainian].

Shakhnazarova, N. (1968). O natcionalnom v muzyke [About national in music]. Moscow: Muzyka [in Russian].

Shumilova, E.I. (1976). Natsionalnoe svoeobrazie baleta [National originality of ballet]. Moscow: Znanie [in Russian].

Teleutsia, V. (2011). Arkhetyp yak osnova natsionalnoho samousvidomlennia [Archetype as the basis of national self-awareness]. Literatura. Folklor. Problemy poetyky, 36, 291-300 [in Ukrainian].

Uralskaia, V. (1969). Esteticheskie problemy vzaimovliyaniya narodnogo i professionalnogo iskusstva (na materiale khoreografii) [Aesthetic problems of the mutual influence of folk and professional art (based on choreography)]. (Abstract of PhD Dissertation). Moscow State Institute of Culture, Moscow [in Russian].

Vasylenko, K. (1997). Ukrainskyi tanets [Ukrainian dance]. Kyiv: IPK PK [in Ukrainian]. 